\title{
A comparison of the number of inner cell mass and trophectoderm cells of preimplantation Meishan and Yorkshire pig embryos at similar developmental stages
}

\author{
R. M. Rivera, C. R. Youngs and S. P. Ford* \\ Department of Animal Science, Iowa State University, Ames, IA 50011, USA
}

\begin{abstract}
Day 12 blastocysts from Meishan gilts contain fewer cells than do day 12 blastocysts from Yorkshire gilts. The purpose of this study was to evaluate the effect of breed on the relative numbers of inner cell mass and trophectoderm cells in Meishan and Yorkshire embryos at similar stages. Embryos were collected on days 5.5-6.5 of gestation and were subjected to image analysis and differential cell staining. No breed differences were detected in the thickness of zona pellucida or in the areas of the perivitelline space, embryo proper, blastocoel and inner cell mass at any of the developmental stages examined (compact morula, early blastocyst or blastocyst). However, differences were observed in the pattern of growth of embryos from Meishan versus Yorkshire gilts. The total number of cells of Meishan embryos from Meishan gilts increased progressively from the compact morula through the blastocyst stage, whereas the total number of cells of embryos from Yorkshire gilts remained constant from compact morula through to early blastocyst, and then increased markedly from the early blastocyst to the blastocyst stage. At the blastocyst stage, Meishan embryos contained fewer $(P<0.05)$ cells than did Yorkshire embryos, and this lower number of cells was due entirely to fewer $(P<0.05)$ trophectoderm cells. As the number of inner cell mass cells increased during embryonic growth, Meishan embryos exhibited a slower $(P<0.02)$ increase in the number of trophectoderm cells than did Yorkshire embryos. These results demonstrate that the reduced number of cells present in Meishan embryos results from a selective reduction in the number of trophectoderm, but not inner cell mass, cells.
\end{abstract}

\section{Introduction}

Chinese Meishan pigs are more prolific than European pig breeds, averaging from three to five more piglets per litter (Cheng, 1983). Recent studies from our laboratory have demonstrated a reduced developmental rate of Meishan embryos versus those of European pig breeds both in vivo and in vitro. Youngs et al. (1993) reported that Meishan embryos collected on day 2 after oestrus and cultured in vitro to the early blastocyst stage exhibited a lower total number of cells when compared with Yorkshire embryos. In another study, Anderson et al. (1993) showed that on day 12, average littermate embryonic diameter and DNA content were less for Meishan embryos than for embryos from European white crossbred sows, although the range of embryonic sizes was similar between the two breeds. Those researchers also reported that Meishan embryos produced markedly less oestradiol than did embryos from European white crossbred sows, even when comparing embryos of the same diameter.

During embryonic development, differentiation begins at the time of compaction with the formation of tight cell junctions

*Correspondence.

Received 11 May 1995. between the outermost cells of an embryo. These outer cells are subsequently referred to as trophectoderm cells, and the remaining inner cells of the embryo are known as inner cell mass cells. The inner cell mass cells give rise to the embryo proper, yolk sac and other extraembryonic tissues, and the trophectoderm cells give rise to the chorionic ectoderm (Gardner et al., 1973; Bard and Kaufman, 1994) and are the first site of embryonic oestrogen secretion (Gadsby et al., 1980). Oestrogen, produced by the trophectoderm cells of larger littermate embryos, alters the uterine environment, possibly through changes in endometrial secretory products, making it unsuitable for smaller littermate embryos (Geisert et al., 1982a). An initial, rapid mitotic rate of trophectoderm cells, followed by their morphological changes, results uitimately in elongation and spacing of pig embryos within the uterus (Geisert et al, 1982b). It has been suggested (Ford and Youngs, 1993; Youngs et al., 1994) that Meishan embryos may have the ability to elongate from fewer cells than Yorkshire embryos. Recently, Wilson et al. (1995) confirmed that Meishan embryos elongate from fewer cells and reach a reduced length on day 14 than do Yorkshire embryos.

The objective of the present study was, therefore, to determine whether there are differences in the relative numbers 
Table 1. Reproductive characteristics of Meishan and Yorkshire pig embryo donors ${ }^{2}$

\begin{tabular}{|c|c|c|}
\hline Measurement & $\begin{array}{c}\text { Meishan } \\
(n=12)\end{array}$ & $\begin{array}{l}\text { Yorkshire } \\
(n=11)\end{array}$ \\
\hline Number of oestrous cycles & $\begin{array}{c}3.1 \pm 0.4 \\
\text { (median }=2 \text { ) }\end{array}$ & $\begin{array}{c}2.9 \pm 0.4 \\
(\text { median }=2)\end{array}$ \\
\hline Number of corpora lutea & $14.8 \pm 0.8$ & $16.2 \pm 0.8$ \\
\hline Percentage recovery of embryos (embryo $/$ corpora lutea) & $84 \pm 4$ & $86 \pm 4$ \\
\hline Number of embryos subjected to differential staining ${ }^{c}$ & 138 & 113 \\
\hline
\end{tabular}

${ }^{a}$ Values are presented as least squares means \pm SEM. No differences were observed in any of the parameters measured $(P>0.20)$. ${ }^{b}$ The mean does not include two unfertilized ova. All recovered embryos were of good to excellent quality.

"An additional 11 embryos from the last two Meishan donors and 40 embryos from the last five Yorkshire donors were randomly selected for use in an unrelated study and were not subjected to differential staining.

of inner cell mass and trophectoderm cells among compact morula, early blastocyst and blastocyst stage Meishan and Yorkshire embryos.

\section{Materials and Methods}

\section{Animals}

Meishan $(n=12)$ and Yorkshire $(n=11)$ gilts of similar reproductive age (two to six postpubertal oestrous cycles; Table 1) were checked for oestrus twice a day (08:00 and 17:00 h) with an intact boar. The first observation of behavioural oestrus, irrespective of the time of day, was designated as the beginning of day 0 . Gilts were hand-mated to a boar of the same breed at day 0 and were mated again $24 \mathrm{~h}$ later.

\section{Collection of embryos}

In our population of pigs, the ovulation time following the onset of oestrus is similar for both Meishan and Yorkshire gilts (Youngs et al., 1994), yet Meishan embryonic development has been shown to be slower (Anderson et al., 1993; Youngs et al., 1993). Therefore, to correct for known breed differences in developmental rate, embryos from Meishan gilts were surgically collected on days $6.0(n=94)$ or $6.5(n=44)$ while embryos from Yorkshire gilts were collected on days 5.5 $(n=50)$ or $6.0(n=63$; Table 1). Meishan and Yorkshire gilts were sedated and anaesthetized as described by Youngs et al. (1994). The uterus was exteriorized via midventral laparotomy, and an incision was made in the antimesometrial region of the uterine wall $2-3 \mathrm{~cm}$ from the utero-tubal junction. A borosilicate glass cannula (10 mm o.d. and $10 \mathrm{~cm}$ long) was inserted into the incision pointing away from the oviduct and was kept in place with a silk ligature. Twenty millilitres of Dulbecco's PBS (Biowhittaker, Walkersville, MD) containing 2\% (v/v) fetal bovine serum and $1 \%(\mathrm{v} / \mathrm{v})$ antibiotic-antimycotic $(10000 \mathrm{U}$ penicillin $\mathrm{ml}^{-1} ; 10000 \mathrm{mg}$ streptomycin $\mathrm{ml}^{-1}$ and $25 \mathrm{mg}$ amphotericin-B ml ${ }^{-1}$; AGTECH Inc., Manhattan, KS) was injected via a blunt 18-gauge needle inserted at the base of the cannulated uterine horn. The embryos were moved to the tip of the uterine horn by firmly pushing the flushing medium along the length of the horn, where medium was collected through the cannula into a sterile glass Petri dish.

\section{Classification of developmental stage of embryos}

After collection, the embryos were immediately transferred to modified PBS (mPBS; $0.0036 \%(\mathrm{w} / \mathrm{v})$ sodium pyruvate, $0.0023 \%(\mathrm{w} / \mathrm{v})$ L-glutamine, $0.4 \%(\mathrm{w} / \mathrm{v})$ BSA and $1 \%(\mathrm{v} / \mathrm{v})$ penicillin-streptomycin). The stage of development was determined in all embryos using the International Embryo Transfer Society method (Stringfellow and Seidel, 1990) with modifications made in our laboratory. The criteria used to classify the embryos were: (i) compact morula: embryo had a large perivitelline space, blastomeres had compacted, cell definition was lost, and no blastocoel was present; (ii) early blastocyst: an evident perivitelline space, embryo had two distinct populations of cells, a small blastocoel and (iii) blastocyst: embryo had very little, or no, perivitelline space, a large blastocoel and no evidence of thinning of the zona pellucida.

\section{Immunosurgical lysis and differential staining}

The zona pellucida of each embryo was removed by incubation at $39^{\circ} \mathrm{C}$ for $45 \mathrm{~s}$ in an acidic Tyrode's solution $(0.8 \%$ (w/v) $\mathrm{NaCl}, 0.02 \%(w / v) \mathrm{KCl}, 0.024 \%(w / v) \quad \mathrm{CaCl}_{2} \cdot \mathrm{H}_{2} \mathrm{O}$, $0.01 \%(w / v) \mathrm{MgCl}_{2} \cdot 6 \mathrm{H}_{2} \mathrm{O}, 0.1 \%(\mathrm{w} / \mathrm{v})$ glucose, $0.4 \%(\mathrm{w} / \mathrm{v})$ polyvinyl pyrrolidone; pH 2.5; Hogan et al., 1986). After removal of the zonae pellucidae, embryos were washed three times in mPBS. The embryos were subjected to immunosurgery and were differentially stained by the method of Hardy et al. (1989) with modifications determined to be necessary for pig embryos. Briefly, the embryos were incubated on ice for $30 \mathrm{~min}$ in $10 \mathrm{mmol}$ trinitrobenzene sulfonic acid $1^{-1}$ (TNBS; Sigma Chemical $\mathrm{Co}$, St Louis, MO) to label cell surface proteins with covalently bound trinitrophenol (TNP) groups. This allowed the use of an antiserum against dinitrophenol (DNP) which crossreacts with TNP-labelled proteins. Embryos were then washed three times in mPBS and placed in an anti-DNP antibody solution (ICN Immunobiologicals, Costa Mesa, CA; $0.1 \mathrm{mg} \mathrm{ml} \mathrm{m}^{-1}$ in $\mathrm{mPBS}$ ) for $30 \mathrm{~min}$ at $39^{\circ} \mathrm{C}$. The embryos were again washed three times in $\mathrm{MPBS}$ and were then placed in an mPBS solution containing guinea-pig complement serum (1:5 dilution; Sigma Chemical Co.) and propidium iodide 
(0.01 $\mathrm{mg} \mathrm{ml}^{-1}$; Sigma Chemical Co.) at $39^{\circ} \mathrm{C}$ for $20 \mathrm{~min}$. This step resulted in the lysis of the trophectoderm cells and the red staining of trophectoderm cell nuclei. Immediately after this step, embryos were placed in absolute ethanol containing the fluorochrome bisbenzimide $\left(0.05 \mathrm{mmol} \mathrm{l}^{-1}\right.$. Hoechst 33258 ; Sigma Chemical Co.) for $1 \mathrm{~h}$ at $4^{\circ} \mathrm{C}$. This resulted in the staining of all cell nuclei (intact inner cell mass and lysed trophectoderm) and the fixation of the embryo, with the inner cell mass cell nuclei appearing blue while the trophectoderm cell nuclei appeared pink (due to the combination of the blue and red). Finally, embryos were removed from this solution and were washed by placing them in absolute ethanol for $30 \mathrm{~min}$ at $4^{\circ} \mathrm{C}$. Various controls were conducted to validate the differential staining technique. Controls consisted of omissions of TNBS, antibody or complement individually, or in combination, with the embryo solutions, resulting in the prevention of trophectoderm cell lysis and subsequent blue staining of both trophectoderm and inner cell mass cell nuclei.

Each embryo was individually mounted in a $5 \mu \mathrm{l}$ drop of glycerol on a glass slide, and the two types of nuclei (trophectoderm and inner cell mass) were visualized and counted by use of a fluorescent microscope (Nikon DiaphotTMD) fitted with a UV2A filter combination having a 330$380 \mathrm{~nm}$ excitation filter and a $420 \mathrm{~nm}$ barrier filter. All nuclei of each embryo were counted independently by two operators, and the counts were averaged. Overall, counts of inner cell mass cell nuclei and trophectoderm cell nuclei of the operators were not different $(P>0.45$ and $P>0.77$, respectively).

\section{Image analysis}

Embryos collected from the last six Meishan and last six Yorkshire donors were available for morphological analysis. A randomly selected portion of embryos from some donors were used in another experiment, but the remaining whole or partial litters were photographed for subsequent analysis (Nikon N2020 camera, loaded with Kodak TMX 100 black and white print film). Embryos in which differential staining was successfully accomplished ( $n=35$ Meishan and $n=33$ Yorkshire) were subjected to image analysis as described by Youngs ef al. (1987). Each photographic negative was illuminated using a ChromaPro 45 light box, and the image was conveyed to the computer using a Sony DXC-3000A video camera equipped with a Contax $60 \mathrm{~mm}$ Macro lens. The captured image of each embryo was then traced, and each image was evaluated with a Zeiss SEM-IPSA Image Analysis System (Zeiss-Kontron: IBAS version 2.0). The image analysis data were used to determine the thickness of the zona pellucida, and the areas of the perivitelline space, embryo proper, blastocoel and inner cell mass.

\section{Statistical analyses}

Data from the subset of embryos subjected to image analysis were analysed using zona pellucida thickness, perivitelline space area, area of embryo proper, blastocoel area and inner cell mass area as dependent variables. Data were analysed using the General Linear Model (GLM) procedure of the Statistical Analysis Systems (SAS, 1985). Breed effects were tested using

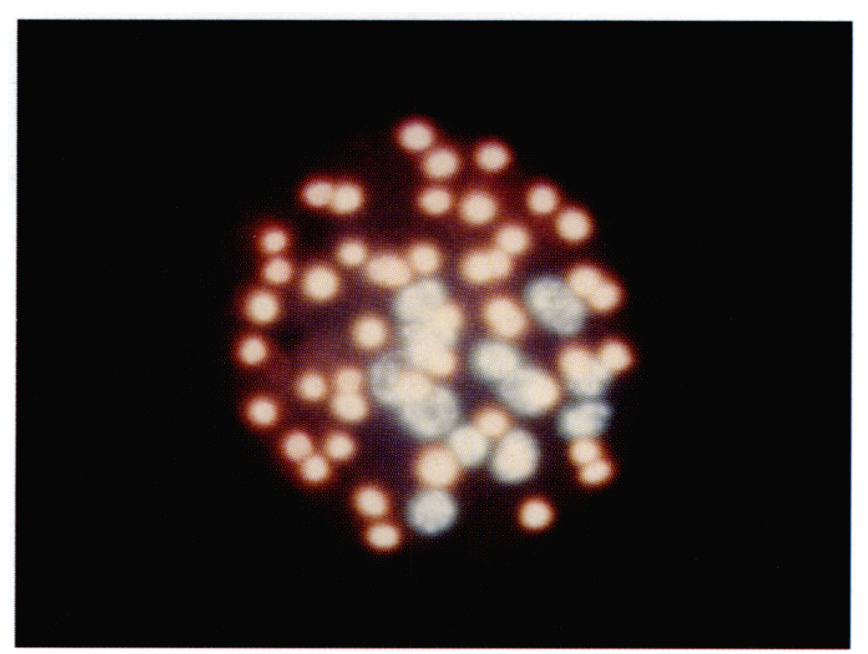

Fig. 1. A differentially stained day 6 blastocyst from a Yorkshire pig $(\times 200)$. The blue objects are the nuclei of the inner cell mass cells, and the pink objects are the nuclei of the trophectoderm cells.

gilt within breed as the error term. Furthermore, Student's $t$ test was used to determine whether there was an effect of operator on the numbers of inner cell mass and trophectoderm cells per embryo, if the number of total cells differed between and within breeds at a particular stage of development, and if the slopes of the regression lines were different. Results were considered significant at the $P<0.05$ level. The results are presented as least squares means \pm SEM.

\section{Results}

The number of ovulations and the number of embryos recovered did not differ $(P>0.05)$ between breeds (Table 1$)$. Embryos collected from Meishan gilts on days 6.0-6.5 yielded the same range of developmental stages (compact morula, early blastocyst and blastocyst) as embryos collected from Yorkshire gilts on days 5.5-6.0. Not all attempts at differential staining were successful, as many compact morulae yielded only pink nuclei and some other embryos became fragile and the nuclei were disrupted. In the latter case, these embryos were excluded from the analysis to avoid influencing biological interpretation of the data because of methodological difficulties. Differential staining was successfully accomplished in 94 embryos from each breed (Fig. 1) and was not affected by breed of embryo $(P>0.10)$. Image analysis demonstrated no breed differences at any of the embryonic stages examined in the thickness of the zona pellucida, or in the area of the perivitelline space, blastocoel, embryo proper and inner cell mass (Table 2).

Breed differences were observed in the pattern of embryonic growth from the compact morula to the blastocyst stage (Fig. $2)$. The total number of cells of Meishan embryos increased $(P<0.01)$ from the compact morula to the early blastocyst and again from the early blastocyst to the blastocyst stage $(P<0.01)$. In contrast, the total number of cells of Yorkshire embryos remained relatively constant from the compact morula through the early blastocyst stage but exhibited a marked 
Table 2. Morphological characteristics of embyros from Meishan and Yorkshire gilts ${ }^{a}$

\begin{tabular}{|c|c|c|c|c|c|c|}
\hline \multirow[b]{2}{*}{ Measurement } & \multicolumn{3}{|c|}{ Meishan } & \multicolumn{3}{|c|}{ Yorkshire } \\
\hline & $\begin{array}{c}\text { Compact } \\
\text { morula } \\
(n=13)\end{array}$ & $\begin{array}{c}\text { Early } \\
\text { blastocyst } \\
(n=12)\end{array}$ & $\begin{array}{c}\text { Blastocyst } \\
(n=10)\end{array}$ & $\begin{array}{c}\text { Compact } \\
\text { morula } \\
(n=3)\end{array}$ & $\begin{array}{c}\text { Early } \\
\text { blastocyst } \\
(n=8)\end{array}$ & $\begin{array}{c}\text { Blastocyst } \\
(n=22)\end{array}$ \\
\hline Thickness of zona pellucida $(\mu \mathrm{m})$ & $10.58 \pm 0.51$ & $10.65 \pm 0.87$ & $9.39 \pm 0.90$ & $8.93 \pm 0.93$ & $10.92 \pm 0.95$ & $10.20 \pm 0.69$ \\
\hline Area of blastocoel $\left(\mu \mathrm{m}^{2}\right)$ & - & $3474 \pm 1853$ & $5017 \pm 1284$ & - & $2627 \pm 1644$ & $2892 \pm 933$ \\
\hline Area of inner cell mass $\left(\mu \mathrm{m}^{2}\right)$ & - & $2490 \pm 836$ & $4201 \pm 1323$ & - & $2287 \pm 966$ & $4882 \pm 1154$ \\
\hline
\end{tabular}

a Data were obtained through image analysis, and values presented are least squares mean \pm SEM. No differences were observed in any of the characteristics measured $(P>0.1)$.

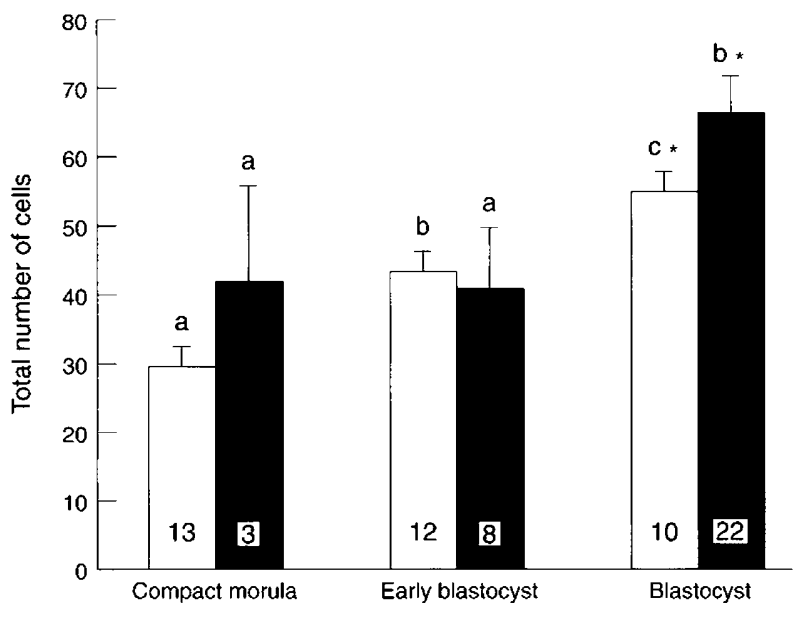

Fig. 2. Growth patterns (number of nuclei counted per embryonic stage) of compact morulae, early blastocysts and blastocysts of ( $\square$ ) Meishan and ( $\boldsymbol{\square}$ ) Yorkshire gilts on which image analysis was performed. Each bar represents the least squares mean \pm SEM of the number of cells in embryos at each developmental stage. The number of embryos used to generate the mean is indicated inside each bar. Values with different letters are significantly different $(P<0.01)$ within a breed in the number of total cells from one developmental stage to the next. Asterisks denote differences $(P<0.05)$ between breeds for that developmental stage.

increase $(P<0.01)$ from the early blastocyst to the blastocyst stage. By the blastocyst stage, the total number of cells in Meishan and Yorkshire embryos differed $(P<0.05)$, and blastocysts from Meishan gilts had approximately 11 fewer cells than did Yorkshire blastocysts. The reduction in the total number of cells observed in Meishan blastocysts was due entirely to a decrease in the number of trophectoderm cells $(44.1 \pm 2.71$ versus $52.55 \pm 3.68 ; P<0.05)$ and not to a difference in the number of inner cell mass cells (10.80 \pm 1.46 versus $13.63 \pm 2.01 ; P>0.10)$ in Meishan versus Yorkshire blastocysts, respectively.

As the number of cells of the inner cell mass increased, the number of trophectoderm cells in Meishan embryos accumulated more slowly $\left(y=1.40 x+19.25 ; r^{2}=0.77\right)$ than those of Yorkshire embryos $\left(y=2.82 x+16.18 ; r^{2}=0.83\right)$ resulting in regression lines (Fig. 3) with different $(P<0.02)$ slopes. The

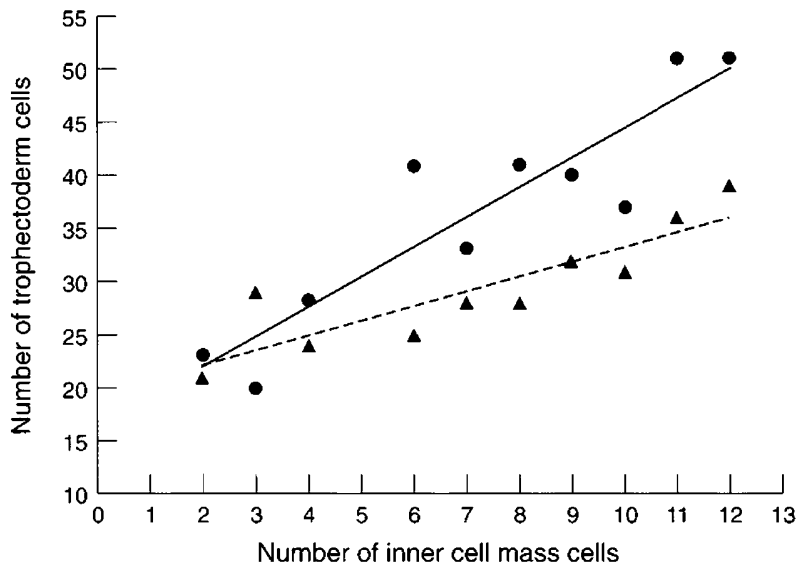

Fig. 3. Distribution of trophectoderm cells as the number of inner cell mass cells increase in $(\boldsymbol{O})$ Yorkshire and $(\boldsymbol{\Delta})$ Meishan embryos. Each point on the graph represents an average of 2-8 Yorkshire embryos collected from each of 2-7 Yorkshire gilts or an average of 3-10 Meishan embryos collected from each of 2-8 Meishan gilts.

inner cell mass cell to trophectoderm cell ratio increased in Meishan embryos from the compact morula to the early blastocyst stage $(0.29$ and 0.36 , respectively) and then decreased at the blastocyst stage $(0.25)$. Yorkshire embryos demonstrated a different pattern of growth from Meishan embryos with a continuous decrease in the inner cell mass cell to trophectoderm cell ratio from the compact morula $(0.32)$ to the early blastocyst $(0.30)$ and blastocyst (0.25) stages of development.

\section{Discussion}

Although it is known that embryos from Meishan pigs contain fewer cells than do contemporary Yorkshire embryos throughout the preimplantation period (day 6: Youngs et al., 1993; and day 12: Anderson et al., 1993; Youngs et al., 1994), the present study is the first to report the specific cell type(s) involved. To accomplish this goal, we modified a differential staining technique (originally adapted for human embryos) that enabled the number of inner cell mass and trophectoderm cells comprising 
Meishan and Yorkshire embryos to be quantified and compared. The embryonic developmental stages observed in this experiment (compact morula, early blastocyst and blastocyst) were comparable to those found by other investigators on the same days of early gestation in the pig (Heuser and Streeter, 1929; Papaioannou and Ebert, 1988; te Kronnie and de Boer, 1993). In addition, image analysis data provided corroboration of similarities in morphology between Meishan and Yorkshire embryos at each developmental stage, consistent with previous findings (Youngs et al., 1993). Furthermore, the number of cells comprising individual embryos from the compact morula to the blastocyst stages of development were in the range of those reported previously for pig embryos by other researchers (Papaioannou and Ebert, 1988; te Kronnie and de Boer, 1993; Rath et al., 1995; Tao et al., 1995).

These data demonstrated that the lower number of cells observed in Meishan versus Yorkshire blastocysts was predominantly due to fewer trophectoderm cells. In addition, breed differences were observed in the pattern of embryonic development from the compact morula to the blastocyst stage. As embryos developed from the compact morula to the early blastocyst stage, both the inner cell mass cell and trophectoderm celi populations increased in Meishan embryos. In contrast, no increases were observed between these stages in Yorkshire embryos. From the early blastocyst to the blastocyst stage, however, patterns of embryonic cell growth were similar in both Meishan and Yorkshire embryos, as the only observed change was an increase in the number of trophectoderm cells. Although the number of Yorkshire compact morulae was limited, data from the present study are consistent with those of Heuser and Streeter (1929), who reported that the increase in the total number of cells observed from day 5 to day 6 for pig embryos reflected increases in smaller and more flattened outer cells (that is, trophectoderm cells).

In a number of studies performed in our laboratory over a period of years, we have consistently found a reduced total number of cells in Meishan compared with Yorkshire (or white crossbred) embryos. Meishan early blastocysts have fewer cells than do Yorkshire early blastocysts (Youngs et al., 1993), and Meishan embryos possess fewer cells than Yorkshire embryos on day 12 following natural mating (Anderson et al., 1993) or embryo transfer (Youngs et al., 1994). However, data on the number of cells contained by day 7-9 Meishan and Yorkshire embryos have not been collected owing to limitations of currently available technologies (that is, differential staining and DNA analysis). During our refinement of the differential staining technique we found that it was very difficult to count $>200$ cells (that is, embryos beyond day 7 of gestation). Furthermore, DNA analysis is not sufficiently sensitive to assess DNA in individual embryos before day 10 of gestation. Recently, however, we have analysed day 10.5 blastocysts of Meishan and Yorkshire gilts and found that, consistent with our observations on day 6 and day 12 embryos, Meishan embryos contained less DNA than did Yorkshire embryos (S. P. Ford, unpublished). In addition, Wilson et al. (1995) demonstrated that the mitotic rate (as measured by proliferating cell nuclear antigen) of trophectoderm cells was significantly lower in day 11.5 Meishan versus Yorkshire blastocysts. Thus, the lower number of trophectoderm cells observed in day 12 Meishan embryos seems to result from both a slower mitotic rate and a smaller initial population of trophectoderm cells at the time of blastocyst formation.

Data on the comparative growth rate of preimplantation embryos from Meishan and European pig breeds have been collected in other laboratories. Bazer et al. (1988) reported that Meishan embryos were smaller than Large White embryos on day 8 but were larger than Large White embryos on days 10-12. In contrast, Wilmut et al. (1992) found no difference in the size or developmental stage of Meishan and European pig embryos collected 18-219 h after the estimated time of ovulation. The results of the present study are difficult to compare directly with those of Bazer et al. (1988) and Wilmut et al. (1992) because of asynchrony between breeds in the estimated time of ovulation and, hence, the time of embryo collection. Had the Meishan embryos in the present study been collected several hours later than Yorkshire embryos, similar results may have been obtained. In several studies, however, no obvious breed differences in the time of ovulation have been observed between our Meishan and Yorkshire females (Anderson $e t$ al., 1993; Youngs et al., 1993, 1994).

Although experiments are needed to test the hypothesis, we propose that events occurring during early embryogenesis directly influence embryonic survival and litter size in the Meishan breed. Meishan embryos with a reduced number of trophectoderm cells (present study) apparently give rise to day 12 embryos that possess fewer cells and contain less oestradiol (Anderson et al., 1993) than do embryos from European pig breeds. A reduced embryonic oestradiol secretion presumably results in a more gradual change in uterine environment that is more conducive to embryonic survival (Pope, 1992). Furthermore, Meishan embryos elongate from a reduced total number of cells (Youngs et al., 1994) and develop into conceptuses that contain approximately $50 \%$ as many cells and are about $70 \%$ as long on day 14 as Yorkshire embryos (Wilson et al., 1995). These observations are biologically consistent with numerous other studies reporting a reduction in conceptus size for Meishan versus European pig breeds at day 30 (Ashworth et al., 1990, 1992; Ford et al., 1994) and day 90 of gestation (Rivera et al., 1994), as well as at term (Biensen et al., 1995).

The number of trophectoderm cells present at elongation may dictate the maximum length of an embryo and, thus, the space within the uterine horn it ultimately occupies. It has been suggested that each fetus in European breeds of pig requires a certain length of uterine horn to survive (Knight et al., 1977; Dziuk, 1985; Wu et al., 1989). Furthermore, about $10 \%$ of prenatal mortality in domestic pigs occurs after day 30 of gestation as a result of fetal overcrowding (Bazer et al., 1969; Fenton et al., 1972; Dziuk, 1985). Bazer et al. (1988) reported no breed differences in uterine horn length and width, or in endometrial surface area, on day 30 of gestation between Meishan and Large White gilts. However, they demonstrated that embryo survival and average litter size favoured Meishan over Large White gilts, suggesting that conceptus factors rather than uterine morphology played an important role in embryonic and fetal survival. Collectively, these data suggest that a reduction in the number of trophectoderm cells during early embryogenesis may result in a reduced placenta size and an increased litter size in prolific breeds such as the Meishan. 
The authors thank L. K. Christenson and C. Hertz for technical expertise, M. Shell and T. Randall for animal care, and D. Johnston for preparation of this manuscript. Support from the Japanese Ministry of Agriculture, Forestry and Fisheries and the Iowa State University Biotechnology Council is gratefully acknowledged. Journal paper number J-16336 of the Iowa Agricultural and Home Economics Experiment Station (projects 2443,2444, and 2942), a contribution to regional research project W-171 Germ Cell and Embryo Development and Manipulation for the Improvement of Livestock.

\section{References}

Anderson LH, Christenson LK, Christenson RK and Ford SP (1993) Investigations into the control of litter size in swine: II. Comparisons of morphological and functional embryonic diversity between Chinese and American Breeds Journal of Animal Science 71 1566-1571

Ashworth CJ, Haley CS, Aitken RP and Wilmut I (1990) Embryo survival and conceptus growth after reciprocal embryo transfer between Chinese Meishan and Landrace $\times$ Large White gilts Journal of Reproduction and Fertility 90 595-603

Ashworth CJ, Haley CS and Wilmut I (1992) Effects of Regumate on ovulation rate, embryo survival and conceptus growth in Meishan and Landrace $\times$ Large White gilts Theriogenology $37433-443$

Bard JBL and Kaufman MH (1994) The mouse. In Embryos: Colur Atlas of Development pp 183-206 Ed. JBL Bard. Wolfe Publishing, Edinburgh

Bazer FW, Clawson AJ, Robinson OW and Ulberg LC (1969) Uterine capacity at two stages of gestation in gilts following embryo superinduction Journal of Animal Science 29 30-34

Bazer FW, Thatcher WW, Martinet-Botte F and Terqui M (1988) Conceptus development in Large White and Prolific Chinese Meishan Pigs Journal of Reproduction and Fertility 84 37-42

Biensen NJ, Wilson ME, Youngs CR and Ford SP (1995) Differential vascular density in Meishan versus Yorkshire placentae in the same uterine environment Biology of Reproduction 52 (Supplement 1) 180 (Abstract)

Cheng P-L (1983) A highly prolific pig breed of China - the Taihu pig (Parts I and II) Pig News and Information 4 407-425

Dziuk PJ (1985) Effects of migration, distribution and spacing of pig embryos on pregnancy and fetal survival Journal of Reproduction and Fertility Supplement 33 57-63

Fenton FR, Schwarts FL, Bazer FW, Robinson VW and Ulberg LC (1972) Stage of gestation when uterine capacity limits embryo survival in gilts Journal of Animal Science 35 383-388

Ford SP and Youngs CR (1993) Early embryonic development in prolific Meishan pigs Journal of Reproduction and Fertility Supplement 48 271-278

Ford SP, Christenson LK, Rivera RM and Youngs CR (1994) Inhibitory effects of the Meishan uterus on day 30 conceptuses Biology of Reproduction $\mathbf{4 8}$ (Supplement 1) 175 (Abstract)

Gadsby JE, Heap RB and Burton RD (1980) Oestrogen production by blastocysts and early embryonic tissue of various species Journal of Reproduction and Fertilify $60409-417$

Gardner RL, Papaioannou VE and Barton SC (1973) Origin of the ectoplacental cone and secondary giant cells in mouse blastocysts reconstituted from isolated trophoblast and inner cell mass Jourhal of Embryology and Experimental Morphology 30 561-572

Geisert RD, Renegar RH, Thatcher WW, Roberts RM and Bazer FW (1982a) Establishment of pregnancy in the pig: 1. Interrelationships between preimplanation development of the pig blastocyst and uterine endometrial secretions Biology of Reproduction 27 925-939
Geisert RD, Brookbank JW, Roberts RM and Bazer FW (1982b) Establishment of pregnancy in the pig: II. Cellular remodeling of the porcine blastocyst during elongation on day 12 of pregnancy Biology of Reproduction 2794 I-955

Hardy K, Handyside AH and Winston RML (1989) The human blastocyst: cell number, death, and allocation during late preimplantation development in vitro Develupment 107 597-604

Heuser CH and Streeter GL (1929) Early stages in the development of pig embryos, from the period of initial cleavage to the time of the appearance of limb-buds Contributions to Embryology 20 3-29

Hogan B, Costantini F and Lacy E (1986) Manipulating the Mouse Embryo: a Laboratory Manual Cold Spring Harbor Laboratory Press, New York

Knight JW, Bazer FW, Thatcher WW, Franke DE and Wallace HD (1977) Conceptus development in intact and unilaterally hysterectomizedovariectomized gilts: interrelations among hormonal status, placental development, fetal fluids, and fetal growth Journal of Animal Science 44 620-637

Papaioannou VE and Ebert KM (1988) The preimplantation pig embryo: cell number and allocation to trophectoderm and inner cell mass of the blastocyst in vivo and in vitro Development 102 793-803

Pope WF (1992) Embryogenesis recapitulates oogenesis in swine Proceedings of the Society for Experimental Biology and Medicine 199 273-281

Rath D, Niemann H, Tao T and Boerjan M (1995) Ratio and number of inner cell mass and trophoblast cells of in vitro and in vivo produced porcine embryos Theriogenology 43304 (Abstract)

Rivera RM, Christenson LK, Youngs CR and Ford SP (1994) Competitive survival, growth rate, and estrogen secretory activity of Meishan and Yorkshire fetuses Journal of Animal Science 72 (Supplement 2) 78 (Abstract)

SAS (1985) User's Guide (5th Edn) SAS Institute Inc., Cary, NC

Stringfellow DA and Seidel SM (1990) Munual of the International Embryo Transfer Society: a Procedural Guide and General Information for the Use of Embryo Transfer Technology, Emphasizing Sanitary Precautions (2nd Edn) International Embryo Transfer Society pp 14-16 International Embryo Transer Society, Champaign, IL

Tao T, Reichelt B and Niemann H (1995) Ratio of inner cell mass and trophoblastic cells in demi- and intact pig embryos Journal of Reproduction and Fertility $104251-258$

te Kronnie G and de Boer P (1993) Embryonic development in the pig up to the 64-cell stage, with reference to DNA replication and cell cycle times from the third cleavage division Theriogenology 39 919-928

Wilmut I, Ritchie WA, Haley CS, Ashworth CJ, Aitken RP (1992) A comparison of rate of uniformity of embryo development in Meishan and European white pigs Journal of Reproduction and Fertility 95 45-46

Wilson ME, Kaminski MA, Conley AJ and Ford SP (1995) Developmental differences between Meishan and Yorkshire preimplanation conceptuses Biology of Reproduction 52 (Supplement 1) 178 (Abstract)

Wu MC, Chen ZY, Jarrell VL and Dziuk PJ (1989) Effect of initial length of uterus per embryo on fetal survival and development in the pig Journal of Animal Science $67 \quad 1767-1772$

Youngs CR, Pendleton RJ, Rorie RW and Godke RA (1987) The use of a computerized image analysis system for photometric and morphometric measurements of bovine preimplantation embryos Theriogenolog!l 27299 (Abstract)

Youngs CR, Ford SP, McGinnis LK and Anderson LH (1993) Investigations into the control of litter size in swine: I. Comparative studies on in vitro development of Meishan and Yorkshire preimplantation embryos fournitl of Animal Science 71 156 I-1565

Youngs CR, Christenson LK and Ford SP (1994) Investigations into the control of litter size in swine: 1Il. A reciprocal embryo transfer study of early conceptus development Journal of Animal Science 72 725-731 